\title{
STATE GOVERNANCE OF SOCIO-DEMOGRAPHIC PROCESSES IN AGING SOCIETY
}

\author{
Viktor M. Zaharov ${ }^{1 *}$, Oleg V. Bykhtyn², Ivan I. Gulyaev ${ }^{3}$, Natal'ya V. Shevchenko ${ }^{4}$, Maksim V. Selyukov ${ }^{5}$, Larisa N. \\ Shmigirilova ${ }^{6}$ \\ ${ }_{1,2,3,4,5,6}$ Belgorod State University, 85 Pobedy Street, Belgorod, the Belgorod Region, 308015, Russian Federation. \\ Email: *russia@prescopus.com
}

Article History: Received on $21^{\text {st }}$ August 2019, Revised on $29^{\text {th }}$ September 2019, Published on $06^{\text {th }}$ November 2019

\begin{abstract}
Purpose of the study: The main approach of the research is a combination of methodological and applied aspects, including the development of public policy directions aimed at prolonging the active longevity of the Russian population.

Methodology: The research used a statistical analysis of the processing of official statistics of Rosstat, data of international organizations - the United Nations (Population Division), the World Bank, the World Health Organization (WHO); analytical - analysis of regulatory legal acts of Russian and international law in the field of regulation.
\end{abstract}

Results: The authors analyze global and Russian trends in an aging society. The influence of the demographic aging of the population on the socio-economic development of the state is revealed. The main directions of the state policy in relation to the aging problems of the population are determined, and the world experience of solving the indicated problems is studied.

Applications of this study: This research can be used for the universities, teachers, and students.

Novelty/Originality of this study: In this research, the model of state governance of socio-demographic processes in an aging society is presented in a comprehensive and complete manner.

Keywords: population aging, demographic risks, state policy.

\section{INTRODUCTION}

Many states, at the present stage of development, are faced with one of the key problems - the aging of the population. Thus, the proportion of the world's population aged over 60 increased from " $8.7 \%$ in 1980 to $12.7 \%$ in 2017 , and according to UN forecasts, it will continue to grow, reaching 16.4\% in 2030" (Barsukov V.N. 2016; Davydova O.V. 2012). At the same time, it should be noted that the degree and speed of aging vary by country and region. The most developed countries have a more dynamic, long-lasting aging process, while in less developed countries this process is relatively recent.

The aging of the population is a complex economic problem that generates not only negative economic consequences, but also has a number of social, moral, ethical consequences that require an integrated approach (social, economic, and technological) to its solution.

\section{METHODS}

The problem of aging of the population requires the solution of important issues related not only to health care and the social sphere, but also the economic sphere, namely the development and improvement of geriatric services, the health of the elderly, the prevention of disability, the creation of a rehabilitation system, the solution of issues of employment and social security of senior citizens.

The objective aspect of the research problem is the lack of a comprehensive support system for the formation of trajectories of active longevity in the context of the growing additivity of risk factors for premature aging of the Russian population, as well as the low effectiveness of state programs aimed at ensuring active longevity.

The main approach of the research is a combination of methodological and applied aspects, including the development of public policy directions aimed at prolonging the active longevity of the Russian population.

The research used a statistical analysis of the processing of official statistics of Rosstat, data of international organizations - the United Nations (Population Division), the World Bank, the World Health Organization (WHO); analytical - analysis of regulatory legal acts of Russian and international law in the field of regulation

\section{RESULTS}

The aging of the population occurs everywhere and is a complex demographic process that is the result of long-term demographic changes, shifts in population reproduction, the ratio of fertility and mortality, as well as partially migration, and is manifested in an increase in the share of older people in the total population.

"The aging of the population is closely related to the natural biological process of human aging, however, these concepts are far from unequivocal. A person's old age is predetermined by his/her age, and the aging of a population is determined by the share of a group of people of a certain age (for example, 60 years and older) in the total population". According to international standards, society is recognized as actively aging if the share of people aged 65 and over exceeds $7 \%$ of the 
total population. It should be noted that the share of older people in the general structure of the population grows much faster than any other age group. "More and more "old" states appear on the world map with more than 7\% of the population over 65 ". Russia reached the level of $9.6 \%$ back in 1989 ; by 2015 the share of the $65+$ population was $13.5 \%$, and in $2018-14.6 \%$.

At the beginning of the XX century, the aging of the population is most intense in the countries of Western Europe, Japan, and the USA. Today, the most "demographically old" countries are Japan, Germany, Greece, Italy, and Sweden, which is due to the uneven effect of various factors and causes of aging - a decline in the birth rate, as a result of which the share of children among the total population decreases and the share of old people grows, increasing the average duration life, as well as adverse socio-economic and political situation, and the associated high mortality. According to experts, the most acute problem of "aging of the population" is facing European countries (Table 1). For example, in 2018, "every fifth resident in France (the pioneer of aging) is over 65". "The population of Germany is aging the quickest: since 1950, the number of residents over 65 has doubled, and by 2060 it will almost double more. At the same time, the birth rate in Germany is the lowest in Europe. Women in Germany live on average up to 82 years old, men - up to 78 years old. At the same time, in general in Germany, pensioners make up more than 18\%. In Italy - a little less than 17\%, in France - 20\%, despite the fact that their pace of aging is lower than in Germany. This is explained by the fact that the retirement age in France is the lowest in Europe - 60 years" (Kalachikova ON., Barsukov V.N., Korolenko A.V., Shulepov E.B. 2016).

Table 1: Share of elderly people aged 65 and over

\begin{tabular}{llllllll}
\hline & World & Russia & EU & USA & India & China & Japan \\
\hline 1989 & 6.1 & 10.1 & 13.6 & 12.6 & 3.8 & 5.6 & 11.4 \\
\hline 2002 & 7.1 & 13.1 & 16.1 & 12.3 & 4.6 & 7.2 & 18 \\
\hline 2010 & 7.6 & 13.1 & 17.5 & 13 & 5.1 & 8.4 & 22.5 \\
\hline 2015 & 8.3 & 13.5 & 19.1 & 14.6 & 5.6 & 9.7 & 26 \\
\hline 2016 & 8.5 & 13.8 & 19.5 & 15 & 5.8 & 10.1 & 26.6 \\
\hline 2017 & 8.7 & 14.2 & 19.8 & 15.4 & 6 & 10.6 & 27 \\
\hline
\end{tabular}

Source: The World Bank. Database. Population Estimates and Projections.

The aging of the Russian population is quite rapid, due to, on the one hand, irreversible changes in the birth rate, and, on the other, to a reduction in mortality in the older age groups and, as a result, an increase in life expectancy (see Table 2).

Table 2: Trends in indicators of the aging of the population of the Russian Federation

\begin{tabular}{|c|c|c|c|c|c|c|c|c|}
\hline & 1989 & 2002 & 2005 & 2010 & 2015 & 2016 & 2017 & 2018 \\
\hline $\begin{array}{l}\text { total population } \\
\text { (thous. people) }\end{array}$ & $147,021.9$ & $145,166.7$ & 143,801 & $142,856.5$ & $146,267.3$ & $146,544.7$ & $146,804.4$ & $146,880.4$ \\
\hline $\begin{array}{l}\text { average age of total } \\
\text { population (years) }\end{array}$ & 34.9 & 37.6 & 38.2 & 38.9 & 39.5 & 39.6 & 39.7 & 39.8 \\
\hline $\begin{array}{l}\text { the share of persons } \\
\text { aged } 60 \text { years and } \\
\text { older }(\% \text { of the total })\end{array}$ & 15.3 & 18.5 & 17.4 & 18.2 & 19.9 & 20.3 & 20.8 & 21.3 \\
\hline $\begin{array}{l}\text { the share of persons } \\
\text { aged } 70 \text { years and } \\
\text { older }(\% \text { of the total })\end{array}$ & 6.6 & 8.6 & 8.5 & 9.9 & 9.1 & 8.9 & 9.0 & 9.2 \\
\hline $\begin{array}{l}\text { life expectancy at } \\
\text { birth (years) }\end{array}$ & 69.75 & 64.95 & 65.37 & 68.94 & 71.39 & 71.87 & 72.7 & \\
\hline
\end{tabular}

Analyzing the indicators characterizing the aging of the Russian population, we can note the growth of the average age of the Russian population. From 1989 to 2018, it increased by 5 years and reached 39.8 years. This trend is also characteristic of developed countries, however, during the period of reforms (the 90s - 2000), the growth of middle age was provided "from below", that is, life expectancy did not increase, and the number of children (0-14 years old) decreased, while in Europe countries, the growth of the average age of the population is provided by an increase in life expectancy. We can also point out the increase in the share of the population aged 70 years and older.

It should be noted that the aging population of Russia has its own characteristics. If this process occurs in European countries due to low birth rate, low mortality, and high average life expectancy of the population, then Russia is characterized by low birth rate, high death rate, and low average life expectancy relative to a number of countries. According to the World Bank, life expectancy at birth in Russia in 2017 was 67.1 years for men and 77.4 years for women, while in Austria - 79.3 years and 84.1 years; in Sweden - 80.6 and 84.1 years; in Ireland - 80.2 and 83.8 years; in Germany 
-78.6 and 83.5 years; in Finland - 78.6 and 84.4 years; in France - 79.5 and 85.7 years, respectively. The Russian peculiarities include the remaining disparities of the older age groups by gender, although it has become smooth in recent years. The gender imbalance of the age structure in Russia is expressed much brighter compared with the countries of Western Europe and even the former republics of the Soviet Union (Table 3). Of particular importance, in the context of the aging population, is the increase in life expectancy, which influences the structure of the entire life cycle of an individual. According to the data of the demographic forecast of Rosstat, the "life expectancy at birth will approach values for developed countries only by 2035 and will make (by the average forecast) 80.3 for women and 81.7 (the most), and for men - 71.5 and 74.6 years, respectively". However, the World Bank gives more pessimistic forecasts, according to which, by 2035 , life expectancy at birth for Russian women will reach 79.2 years, and for men - only 68.8 years

Table 3: Life expectancy at birth in Russia and post-Soviet countries

\begin{tabular}{|c|c|c|c|c|c|c|c|c|c|}
\hline & \multicolumn{9}{|c|}{ Life expectancy at birth } \\
\hline & 2015 & & 2016 & & 2017 & & & 2030( & orecast) \\
\hline & 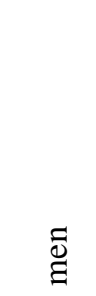 & 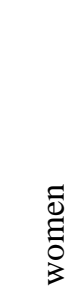 & 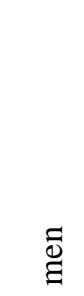 & 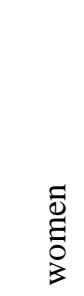 & Фี & 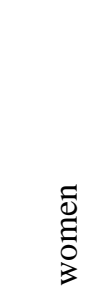 & 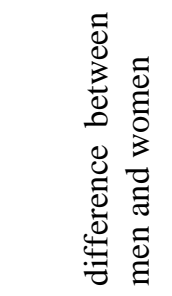 & $\underset{\Xi}{\mathbb{\Xi}}$ & 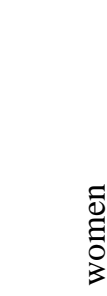 \\
\hline Russian Federation & 65.9 & 76.7 & 66.5 & 77.1 & 67.1 & 77.4 & 10.3 & 67.9 & 78.6 \\
\hline Armenia & 71.1 & 77.5 & 71.3 & 77.6 & 71.4 & 77.8 & 6.4 & 73.7 & 79.8 \\
\hline Azerbaijan & 68.9 & 74.9 & 69 & 75 & 69.1 & 75.2 & 6.1 & 70.4 & 76.8 \\
\hline Belarus & 68.6 & 78.9 & 68.9 & 79.0 & 69.3 & 79.2 & 9.9 & 70.0 & 80.2 \\
\hline Georgia & 68.8 & 77.3 & 69.0 & 77.5 & 69.2 & 77.6 & 8.4 & 71.5 & 79.5 \\
\hline Kazakhstan & 67.5 & 76.9 & 68.1 & 76.6 & 68.7 & 76.9 & 8.2 & 67.4 & 77 \\
\hline Moldova & 67.2 & 75.8 & 67.3 & 75.9 & 67.4 & 76.0 & 8.6 & 69.2 & 77.6 \\
\hline Tajikistan & 68.2 & 74.0 & 68.3 & 74.2 & 68.4 & 74.4 & 6.0 & 70.3 & 76.6 \\
\hline Turkmenistan & 64.3 & 71.2 & 64.4 & 71.3 & 64.5 & 71.4 & 6.9 & 65.9 & 73.2 \\
\hline Ukraine & 66.4 & 76.3 & 66.7 & 76.5 & 67.0 & 76.8 & 9.8 & 69.4 & 78.9 \\
\hline Uzbekistan & 68.5 & 74.0 & 68.6 & 74.1 & 68.6 & 74.2 & 5.6 & 70.0 & 76.0 \\
\hline
\end{tabular}

Source: The World Bank. Database. Population Estimates and Projections.

Health assessment is important for political decision making. This is primarily due to the fact that "a very important question arises with a change in the state of health of whether an increased number of years of life has been spent with a satisfactory state of health or disability or dependent status". Ustinova, O. V. (2014).

If people live these additional years of life in good health, their ability to realize what they consider valuable will differ little from the abilities of younger people. If these additional years are accompanied by a decrease in physical and mental abilities, the consequences for the elderly themselves and for society will be much more negative.

According to current data (2016) of the World Health Organization (WHO), the world average healthy life expectancy was 63.3 years (men - 62.0, women - 64.8). Russia, according to the WHO rating for the average "healthy" life expectancy, ranks 103 out of 184 (WHO publishes data for 184 countries of the world). In 2000-2016, the healthy life expectancy in Russia increased by 5.5 years (see Table 4 ).

Table 4: Healthy life expectancy for Russia

\begin{tabular}{llllll}
\hline & 2000 & 2005 & 2010 & 2015 & 2016 \\
\hline HALE at birth (years) & 58 & 58.1 & 61 & 63.1 & 63.5 \\
\hline Male & 52.5 & 52.8 & 56.3 & 58.7 & 59.1 \\
\hline Female & 63.4 & 63.7 & 65.7 & 67.3 & 67.5 \\
\hline HALE at age 60 (years) & 12.5 & 12.7 & 13.7 & 14.7 & 14.9 \\
\hline Male & 10.1 & 10.2 & 11.2 & 12.2 & 12.4 \\
\hline Female & 14.4 & 14.6 & 15.5 & 16.5 & 16.7 \\
\hline
\end{tabular}


Source: The World Bank. Database. Population Estimates and Projections. World Health Organization. Healthy Life Expectancy (HALE)

The territorial diversity of the aging population of the Russian Federation deserves attention. "The intensity of aging of the population usually increases from east to west and from north to south, which is associated with the territorial features of the natural reproduction regime, and also to a large extent with the migration flows of the population, including young people. Its outflow from the countryside to the cities also has a direct impact on the degree of aging of the rural population, which differs from the urban one".

Until recently, the problem of the aging of the population was not recognized as a global problem, since it seemed that it concerned only a few countries and its consequences could not have large-scale consequences. Now, it becomes obvious that the aging of the population leads to an inherent crisis of the health care system and the social security system, which affects all segments of the population. In addition, it became clear that the aging of the population will not reach its peak by 2020 , as was previously assumed, and that soon all societies will feel the effects of this phenomenon. This also applies to developed countries, where the aging of the population has been going on for a long time, and developing countries, where it has not yet reached its climax but continues growing very fast.

In particular, it leads to a significant increase in the demographic load on the able-bodied population, which is one of the most important aspects of ensuring sustainable territorial socio-economic development. In general, globally, the burden on the working-age population decreased until 2010 (with the exception of the most developed countries) (see Figure 1), which is caused by a decrease in fertility and mortality, leading to the most economically favorable situation when the share of the working population reaches its maximum. However, most countries have already exhausted their demographic dividends, and the burden on the working-age population has increased and according to forecasts of the World Bank will continue to grow.

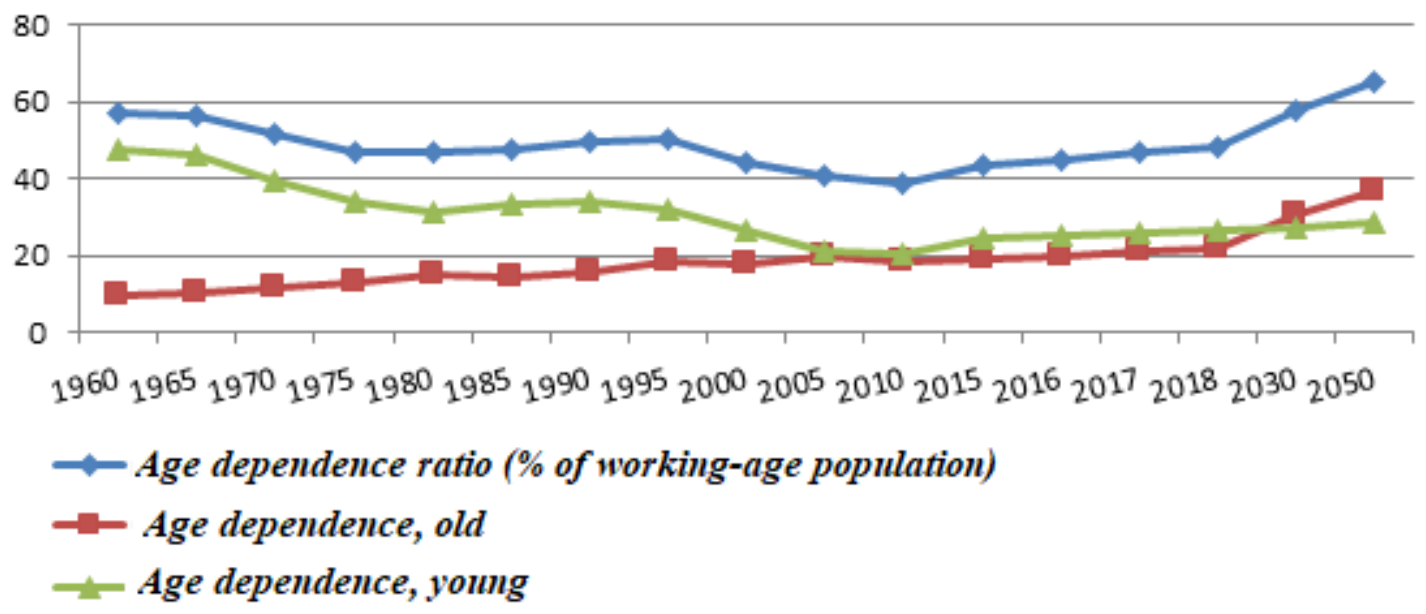

Figure 1: Change in global demographic load, fact, and forecast

The aging of the population has negative consequences and affects almost all spheres of society. Demographic aging of society causes a number of changes in economic and social institutions: it transforms labor potential, changes the ratio of the economically active and inactive parts of the population, and creates new challenges for the economic and social development of society. The aging of the population, due to its scale, is becoming one of the factors changing the social structure of society. Under the influence of this process, different proportions between different segments of the population are formed, their placement over the territory, the degree of homogeneity, typical average parameters such as size, stability, mobility, behaviors, values, and others change. The increase in the share of elderly people places higher demands on the system of settlement, transport, and communications. New requirements are imposed in the sphere of public, domestic, cultural services, that is, to all elements of the social infrastructure, which causes new challenges to public administration under the demographic aging of society.

Such consequences of the aging of the population require the implementation of appropriate reforms aimed both at maintaining a decent level and quality of life of the older generation and at creating conditions for the implementation of the resource potential of this group of population.

The prevailing contradiction is typical for Russia: "on the one hand, a change in the share of socio-demographic groups in the population structure leads to a transformation of the mechanism of the labor market, which requires promoting employment of people of the retirement age, on the other, there is an awareness of the social status of older people who remain one of the most vulnerable categories of the population, whose physical and psychological state quite often prevents them from continuing to work at older age". 
At the present stage of development, the government of the Russian Federation redoubled its attention to the issues of resolving the problems of population aging, which is reflected in a number of federal regulatory legal acts on the implementation of state policy in relation to the older population. Among them are the founding documents in the field of social support for the older generation: the state program "Social Support to Citizens", adopted in 2014, which subprogram "Modernization and Development of Social Services for the Population" deal with issues of social services for senior citizens.

Among the strategic documents affecting the problem of the aging of the population, the 2025 Concept of the demographic policy of the Russian Federation can be noted. However, we should remember that "the problem of population aging in this document is limited to only one reference. This problem is not considered among the measures to implement the concept. Meanwhile, overcoming the consequences of the aging of labor potential requires timely and large-scale work to create the conditions for the voluntary continuation of the work of people of the older age groups. It is especially important to learn how to prolong the working period of life from representatives of professions requiring quite long and expensive training (workers of science, education, culture, specialists in the field of technology, electronics, etc.)".

"An important document that laid the guidelines for modern state policy in the field of active longevity and improvement of the quality of life of elderly Russians was the "2025 Action Strategy for the Benefit of Older Generations in the Russian Federation" adopted in February 2016". The strategic goal of this strategy is to "increase the duration, level, and quality of life of older people".

The current demographic trends set before the state and society of the Russian Federation the task of creating conditions for meeting the basic needs of the older generation, as well as creating the conditions for their active participation in all spheres of society (political, economic, social and others). These areas are reflected in the national project "Demography", in terms of a set of measures to support the system and improve the quality of life of older citizens (the federal project "The Older Generation").

However, despite the relatively large number of legal acts affecting the issues of social support for the older generation, the Russian Federation lacks a comprehensive approach to solving the problems of active aging of the population subject to the changing needs of older citizens and the varying associated opportunities.

The current social status of older citizens in Russia is at a rather low level. Society associates the older generation with retirement, illness, a decrease in all types of activity, inactivity. However, most older people are able to maintain social and personal activity for quite some time. At the same time, they have a vast life and professional experience. Therefore, government policy should be aimed at ensuring the conditions for the more successful integration of this category into the new social status, preservation, and accumulation of the energy of self-development, disclosure, and implementation of the accumulated experience.

World practice has gained great experience in the implementation of measures for the social adaptation of elderly citizens, which can be effectively applied in the formulation of national policies. Thus, in foreign countries, "various social movements are currently developing; organizations for pensioners, where they actively participate in the life of society, engage in volunteer activities, and create various groups of mutual assistance. Old age is considered as a resource for the development of society". The use of resources of the state, commercial, and public organizations is typical for work with older persons abroad.

We may note, for example, that there is no uniform program for the organization of vital activity of the older generation in the UK, since the government, public organizations, and business representatives providing additional services in the field of medical, psychological, and legal support are involved in providing services. In general, "the government policy of Great Britain in relation to elderly citizens and people with disabilities is aimed at creating full-fledged living conditions at home, however, under the supervision of social workers. Frankly speaking, older people are provided with services to maintain vitality while living in a family". "When organizing life and recreation for the elderly, the country focuses on ensuring an atmosphere of benevolent interaction with each other, while age features, interests, and the horizon of the elderly person play a significant role". The practice of "social clubs" organized both on the basis of age criterion and designed to discuss the problems of older people, and on the basis of common interests, is widespread.

France has an interesting experience with the older generation, which is focused on the longest stay of an older person at home. Therefore, two areas of social assistance - "Home Assistant" and "Nursing Care" - are most prevalent. The Home Assistant service organizes social and domestic services at home: buying food, cooking food, house-keeping, washing laundry, paying bills, etc. The organization is financed by the state insurance system or private insurance companies in France. For older people unable to cope with their needs for health reasons, the "Nursing Care" service is organized, which includes both home-based services and the provision of pre-hospital medical care and hygienic services. The grounds for providing such service to an elderly person is the decision of the attending physician, the service itself is provided by nurses and their assistant (nanny). The work of the Nursing Care is to follow medical advice. Services are paid at established rates out of the sickness insurance". 
A significant role in working with older citizens in France is also assigned to club work, the activities of clubs aimed at eliminating social exclusion, organizing leisure, and promoting active participation in public life. The state provides financial assistance to such clubs.

Another point to note is that "France has a Commission of the National Committee of Pensioners and Elderly People. This organization has defined the principles that allow regulating the attitude of public institutions to the elderly. The principle of the dignity of the individual senior citizen. An elderly person has the right to maintenance, qualified and dignified treatment, regardless of health, income, and marital status. The principle of freedom of choice. Every elderly person whose state of health requires specialized intervention has the opportunity to choose their place of stay. The principle of aid coordination. Older people should receive financial assistance from the government; they should live a sheltered life".

As an example, we can note the American experience of creating the "American Association of Pensioners". "The history of the organization is connected with the initiative of the founder Ethel Andrus, who, once retired, continued an active lifestyle, thereby encouraging the rest. Next, the Association was created, which united all the retirees of America, and which still exists today. Various assistance programs have been developed, but much attention is paid to the Generation Together program, where older people are involved in working with young people. The purpose of this program is to create opportunities for hanging out, expanding mutual understanding, transferring the experience and skills of older people".

Continuing labor activity for older people is an opportunity for self-realization, avoiding the feeling of useless and drops out. Experts emphasize the importance of the pension system as one of the most important factors influencing the decision to continue working. The government of many countries, faced with the problem of demographic aging of the population, follows the path of raising the retirement age, which is the simplest and most effective solution to this problem. "Norway implemented a pension reform in 2011, providing for flexible retirement at the age of 62 to 75 years, with the possibility of receiving a pension and earnings and additional savings to a future pension. A number of countries increase the length of labor experience required to receive an early retirement pension. For example, in the Netherlands the work experience has been increased to 40 years, the pension reform of 2005 in Finland has established the so-called "retirement window" from 63 to 68 years, in the range of which the elderly person chooses the retirement age. Thus, the problems of labor activity of older people should be adequately reflected in the comprehensive state policy in the field of aging".

Of course, such reforms have a deep economic justification, but from a demographic point of view, they can lead to a number of demographic risks. Thus, in Russia, the difference between life expectancy and healthy life expectancy is 8.1 years (for 2016). Under these conditions, an "increase in the retirement threshold" may entail an even greater deterioration in the health of the older population, an increase in the number of recipients of disability pensions, the transition of a certain part of the elderly to the shadow sector of the economy, or an increase in unemployment due to pensioners who simply cannot find themselves in the labor market".

Consequently, the questions of not only longevity, but active longevity, which is expressed in maintaining a satisfactory state of health in old age, and the possibility of extending the period of work in old age, become more important.

In order to overcome the consequences of aging of labor potential, it is necessary to ensure that "timely and large-scale targeted work is carried out to increase professional mobility, qualification, retraining, and introduction of continuing education systems for middle and senior age groups within the working-age population, which will make them more competitive in the labor market".

Already in 1991, the Resolution of the United Nations General Assembly 46/91 adopted principles for the elderly. "These include, in particular, the following basic provisions: elderly people should be able to work or engage in other types of income-generating activities; older people should be able to participate in determining the terms and forms of termination of employment; participate in relevant education and training programs; share your knowledge and experience with representatives of the younger generation; be able to fully implement their potential; have access to the possibilities of society in the field of education, cultural life, and recreation".

According to Rosstat's demographic forecasts, the total number of the working-age population of Russia will decline annually by $0.6 \%$, while the total number of people will be maintained, while the number of people over working age will tend to further increase. In this regard, it is necessary to create conditions for more efficient and rational use of resources of the population at retirement age.

According to statistics, over a third of Russian pensioners continue to work today (Table 5). "At the same time, this reserve of labor potential for meeting the needs of the national economy for additional labor, due to the insufficient elaboration of this problem, is still far from being fully used. Not everyone wishing to continue their working career can do it, including due to negative stereotypes about the opportunities of an older employee".

Table 5: Changes in the number of pensioners and the size of their pension coverage (as of January 1)

\begin{tabular}{llllllll}
\hline 2012 & 2013 & 2014 & 2015 & 2016 & 2017 & 2018 & 2019 \\
\hline
\end{tabular}




\begin{tabular}{|c|c|c|c|c|c|c|c|c|}
\hline $\begin{array}{l}\text { Total number of } \\
\text { pensioners, } \\
\text { thousand people }\end{array}$ & 42,367 & 42,837 & 43,327 & 43,797 & 45,182 & 45,709 & 46,071 & 46,480 \\
\hline $\begin{array}{l}\text { The share of the } \\
\text { number } \\
\text { working } \\
\text { pensioners in the } \\
\text { total number of } \\
\text { pensioners, } \%\end{array}$ & 32.4 & 33.7 & 34.9 & 36 & 35.7 & 22.9 & 22.2 & 22 \\
\hline $\begin{array}{l}\text { The average size } \\
\text { of pensions, rub. }\end{array}$ & 8272.7 & 9153.6 & $10,029.7$ & $10,888.7$ & $12,080.9$ & $12,425.6$ & $13,323.1$ & $14,102.1$ \\
\hline $\begin{array}{l}\text { The minimum } \\
\text { subsistence level } \\
\text { of a pensioner, } \\
\text { rub. }\end{array}$ & 5564 & 6131 & 6354 & 7161 & 8803 & 8540 & 8726 & 8846 \\
\hline
\end{tabular}

In Russia, age discrimination in employment starts even long before the retirement age. For example, "the USA in 1967 approved new employment principles, taking into account a person's abilities, rather than his/her age. Currently, in many countries (Canada, France, the Netherlands, etc.), the indication of upper age restrictions are prohibited in job advertisements".

"The activity of state educational institutions, providing information to the elderly on the current needs of the labor market, is aimed at increasing the labor activity of older people. An example is the Kentucky System of State and Technical Colleges programs, as well as the University of Wisconsin's programs, which enable retirees to identify the skills most indemand in the labor market in real-time. The demand for these programs among older people suggests that they can undoubtedly benefit people of retirement age who wish to pursue a working career".

The experience of Great Britain deserves attention, where "at the initiative of public organizations, special workshops were created using simple types of labor and equipment. Many local firms provide free materials and orders for the elderly as charity activities. It should be noted that this kind of support for older people has a positive effect on their vitality, they feel needed for society".

"A direct financial incentive for hiring older workers can be subsidies or tax benefits that reduce employer costs associated with hiring employees in older age groups. Thus, the abolition in 2004 in the Netherlands of one of the social taxes on wages of workers aged 50 years and older resulted in a 5\% reduction in the employer's expenses for this group of employees. In Austria, after reducing the compulsory social taxes on women's wages, starting at 56 years old, and men, starting at 58 years old, the employer's labor costs have decreased by $12 \%$ ".

Thus, the study of the current trends of population aging at the global level and in the Russian Federation, as well as the study of world experience in implementing the directions of state policy in relation to the problems of population aging, to completely unlock the potential of older people, the authorities should change the current practice in the labor market which is focused exclusively on the young, active generation. It is important to encourage employers to create adapted jobs for the older generation and to consider the possibility of using the practice of flexible employment and work with remote access. There is a need to revise the conditions for the formation of pension savings for citizens postponing retirement (in particular, increasing the size of raising coefficients). The most important factor in shaping the conditions for raising the retirement age is the promotion of ideas of health-saving (self-preserving) behavior among the population, which in the future may have a positive impact on the duration of work at older ages.

\section{DISCUSSION AND CONCLUSION}

According to the results of the study, we can conclude that the measures implemented by the government of Western countries are quite effective and can be applied in national practice. Partially, these activities are used in Russia, and this has a positive effect on the livelihoods of older people. At the same time, a promising model for ensuring the level and quality of life of the older generation must meet the following requirements: it must be comprehensive, consider possible changes in the social situation in the country; it must, necessarily, incorporate feedback mechanisms to capture the changes in the society of the older generation; it is necessary to provide an assessment of the effectiveness of the implementation of measures and their adjustment based on the results of the assessment.

\section{REFERENCES}

1. On approval of the 2025 Concept of the demographic policy of the Russian Federation (Text): Presidential Decree No. 1351 of October 09, 2007 (as amended on July 01, 2014) // Collection of legislation of the Russian Federation. - 2017. - No. 42. - Art. 5009. 
2. On approval of the 2025 Action Strategy in the interests of senior citizens in the Russian Federation (Electronic resource): Order of the Government of the Russian Federation No. 164-p of 05.02.2016. - Access mode: http://www.consultant.ru/document/cons doc LAW_193464/780a33fe3eb9d2bf3a74d5d237b24dcd592551a5/.

3. Population ageing and sustainable development (Electronic resource). June 2017 No. 2017/1. - Access mode : https://www.un.org/en/development/desa/population/theme/ageing/index.asp.

4. The World Bank. Database. Population Estimates and Projections (Electronic resource). - Access mode: https://databank.worldbank.org/data/reports.aspx?source=Health\%20Nutrition\%20and\%20Population\%20Statisti cs:\%20Population\%20estimates\%20and\%20projections.

5. Baranenkova T.A. Population aging and its socio-economic consequences (Text) / T.A. Baranenkova // Bulletin of the Institute of Ecology, Russian Academy of Sciences. - 2017. - No. 2. - p. 47-64.

6. Barsukov V.N. Raising the retirement age in Russia: economic necessity and demographic risks (Text) / V.N. Barsukov // Social space. - 2016. - No. 1 (03). - p.3

7. Budaeva S.B. Social adaptation of citizens to the status of a pensioner (Electronic resource) / S.B. Budaeva, N.V. Kondrashov. - Access mode: https://son-net.info/socialnaya-adaptaciya-pozhilyx-grazhdan-k-statusu-pensionera/.

8. Davydova O.V. Experience of social work with older people abroad (Text) / O.V. Davydova // Central Russian Bulletin of Social Sciences. - 2012. - No.4 (1).

9. Kolosnitsina M.G. State policy of active longevity: as evidenced by international experience (Text) / M.G. Kolositsina, N.A. Khorkina // Demographic review. - 2016. - V.3. - No.4. P. 27-46.

10. Li Zhongyuan. State administration under the demographic aging of society. (Text) / Li Zhongyuan. Humanitarian, socio-economic, and social sciences. - 2018. - No.4. - p. 60-62.

11. UN. Economic and Social Council. In-depth analysis of the statistics of the aging population. ECE/CES/2013/9 (Electronic resource). - Access mode: https://www.unece.org/fileadmin/DAM/stats/documents/e ce/ces/20 13/9_R_pdf.

12. Rating of aging nations: countries that expect a crisis (Electronic resource). - Access mode: http://www.profiforex.org/novosti-rossii/entry1008140811.html.

13. According to the World Health Organization. Healthy Life Expectancy (HALE). Countrywise data (Electronic resource). - Access mode: http://apps.who.int/gho/data/node.main.HALE?lang=en\#.

14. The aging planet: the number of pensioners threatens the global economy (Electronic resource). - Access mode: https://www.rbc.ru/economics/23/08/2013/57040e499a794761c0ce0f23.

15. Factors of active longevity: results of a survey of Vologda long-livers (Text) / (Kalachikova ON., Barsukov V.N., Korolenko A.V., Shulepov E.B.) // Economic and social changes: facts, trends, forecast. - 2016. - No.5. - p. 76-94. DOI: $10.15838 / \mathrm{esc} / 2016.5 .47 .4$

16. Murphy, P. A., \& Burnley, I. H. (1993). Socio-demographic structure of Sydney's perimetropolitan region. Journal of the Australian Population Association, 10(2), 127-144.

17. Grzymała-Kazłowska, A. (2013). Migration and socio-demographic processes in central and eastern Europe: Characteristics, specificity and internal differences. Central and Eastern European Migration Review, 2(1), 5-11.

18. Robison, K. K., \& Crenshaw, E. M. (2010). Reevaluating the global digital divide: Socio-demographic and conflict barriers to the internet revolution. Sociological Inquiry, 80(1), 34-62. https://doi.org/10.1111/j.1475682X.2009.00315.X

19. Buja, A., Guarnieri, E., Forza, G., Tognazzo, F., Sandonà, P., \& Zampieron, A. (2011). Socio-demographic factors and processes associated with stages of change for smoking cessation in pregnant versus non-pregnant women. BMC women's health, 11(1), 3. https://doi.org/10.1186/1472-6874-11-3

20. Muethel, M., Gehrlein, S., \& Hoegl, M. (2012). Socio-demographic factors and shared leadership behaviors in dispersed teams: Implications for human resource management. Human Resource Management, 51(4), 525-548. https://doi.org/10.1002/hrm.21488 